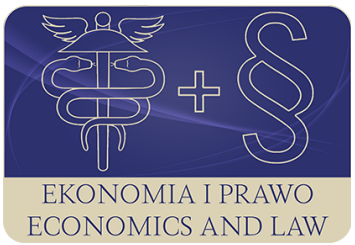

EKONOMIA I PRAWO. ECONOMICS AND LAW

Volume 15, Issue 3, September 2016

p-ISSN 1898-2255, e-ISSN 2392-1625

www.economicsandlaw.pl

ORIGINAL ARTICLE

received 30.09.2015; revised 26.06.2016; accepted 30.09.2016

Citation: Wosiek, M. (2016). Social capital under conditions of economic crisis - the example of Southern European countries. Ekonomia i Prawo. Ecomomics and Law, 15(3): 401-414. doi:10.12775/EiP.2016.027.

\title{
Social capital under conditions of economic crisis - the example of Southern European countries
}

\author{
MAGORZATA WOSIEK \\ University of Rzeszów, Faculty of Economics, Department of Microeconomics, \\ ul. Ćwiklińskiej 2, 35-601 Rzeszów, Poland \\ \mwosiek@ur.edu.pl
}

\begin{abstract}
Aim: Deliberations of the article revolve around trends of social capital under conditions of economic crisis.

Motivation: Final conclusions are based on theoretical considerations and empirical research. The latter include analysis of changes in indicators of social capital (in the cognitive, structural and behavioural dimension) in Southern European countries (Spain, Greece and Portugal) — from comparative perspective — before and after 2007. Data

from European Social Survey and European Value Study were used. The example of Southern European countries shows that there can be no universal reaction scheme (in terms of social capital) on the crisis phenomena.

Results: A common feature of the analyzed countries after 2007 is an increase in ties with friends (bonding social capital, however the heightened importance may not just be a consequence of the crisis, but rather part of long-term societal change - e.g. Portugal) and a reduction in institutional and systemic trust. It can be also concluded that countries well endowed in social capital (e.g. Spain), in the period of economic crisis to the greater extent employ social capital resources as a response to non-beneficial changes in the economic environment (which is illustrated by higher rates of civic and political participation).
\end{abstract}

Keywords: social capital; economic crisis; Southern European countries JEL: Al3; O52; Z13 


\section{Introduction}

Social capital plays a vital role in numerous spheres of human activity. In the economic dimension it can be interpreted metaphorically as a kind of binding agent, a factor integrating the other, material and non-material forms of capital. In the public sphere social capital coordinates individual and collective actions, allows 'participants to act together more effectively to pursue shared objectives' (Putnam, 1995a, pp. 664-665) determines the scale of citizens' involvement, complements deficiencies of formal institutions. Its role in socio-economic life in the 21st century can be summarised by calling it a singular determinant of 'civilisation competences' which are indispensable for stable and efficient functioning of a democratic political system and market economy (Sztompka, 2007, p. 41).

Taking into account the social capital category in analyses of socio-economic phenomena, it fits into broader discourse resulting from the growing interest in soft cultural variables and exhaustion (e.g., due to excessive cognitive reductionism) of the hard-line approach based on too narrowly defined economic rationality. Therefore, discussion around social capital stems from perceiving the significance of non-economic factors affecting the development of social and economic reality. In economy, identification of relations between social capital and economic activity is usually concentrated around the role of social capital for economic development. Relatively less consideration is given to reflexive relations, i.e. the influence of economic processes on social capital transformations. This topic - how the macro-performance of economies (during the crisis) translates into social capital's changes - is raised in the present study.

Taking into account the character of social capital change, which by nature is a long-term one, it could be doubted whether short-term twists in the socio-economic environment (economic crisis can be regarded as such) are capable of affecting the development trajectory of this capital? It turns out that, despite the low susceptibility to change of social capital, it is a heterogeneous category, comprising in its structure cognitive, structural and behavioural components which are characterised by varying sensitivity to phenomena occurring in the macro-environment. Hence it is reasonable to pose a research question, how do impulses generated by economic crisis impact the resources of social capital? Which of the social capital components react to changes of the economic situation, and how? Does social capital become stronger in recession, or does it erode? Can we talk about a universal pattern of reaction to crisis events, e.g., among the different European countries? The aim of this article is to seek answers to the questions raised above. The basis for formulating conclusions, beside theoretical musings, are also empirical analyses. They cover changes of indices diagnosing social capital in South European countries, which has been afflicted more strongly by the last few years' crisis: Spain, Portugal and Greece. 
There were used data from before and after 2007, provided by the European Social Survey and the European Value Study.

\section{Theoretical background and methodological approach}

The fundamental theoretical reference for the majority of studies devoted to social capital issues are the works of J.S. Coleman (1990, p. 304, 313), R. Putnam (1995b, p. 258) and F. Fukuyama (2000, p. 24). From the social capital definitions presented by them emerge elements making constituting its structure, and also indices which permit diagnosis of its condition (table 1). These are (Grootaert \& van Bastelaer, 2002, p. 44):

- the cognitive dimension - it provides that social capital is rooted in the culture, arises from the standards, values declared and practised in a society. An important component of this dimension is trust;

- the structural dimension - it encompasses a network of links of an entity with its surroundings;

- the behavioural dimension - it refers to the manifestations of joint action (civil society indices).

Although changes in social capital are observable in the generational perspective (notably the cognitive dimension), paradoxically it is also a dynamic category, in the sense that the dynamic-decision-making origins of social capital resources. Social capital provides any human activity with axiological orientation (people define their goals on the basis of a system of values), normative orientation (action means are chosen on the basis of norms and standards), as well as cognitive orientation (information is arranged and interpreted using a system of norms and values). The dynamic manifestation of social capital's activity are interpersonal behaviours and relations (behavioural dimension) and these matter especially for response to crises.

The primary components of social capital distinguished above also have an internal taxonomy. As regards the structural dimension, from the point of view of affecting social capital, there are distinguished ties of a bridging (open), bonding (closed) or linking character. Positive, growth-promoting action is attributed to bridging. It relies on so-called generalised trust, improves the ability to work with strangers, facilitates exchange of resources, ideas and information. Whereas bonding is characteristic first of all for closed and uniform communities (family, circles of neighbours, ethnic groups), are based on personal trust and reduce the ability to work with strangers (because they are oriented towards reinforcing a group's internal identity). Linking social capital refers to ties between groups and people in positions of authority or influence. It increases access to formal decision-making processes (Kostro, 2005, pp. 4-5).

Another fundamental component of social capital, which is trust, is a relatively broad category. P. Sztopmka (2007, p. 36) defines it in the most general terms as the 'expectation of honest behaviour towards us', and A. Matysiak (2005, p. 215) clarifies that this is about behaviour consistent with the rules 
of conduct and a specific system of values. Taking into consideration the primary recipients of trust, the literature attributes the most significance (as far as social capital is concerned) to so-called generalised social trust, which goes beyond the circle of family members and includes people whom we do not know personally. This type of trust is of a horizontal character and links (often with informal bonds) the members of particular communities. A more abstract case is institutional trust (of a vertical character), towards public institutions (such as courts, police, government, banks, parliament, etc.), and an even greater degree of abstraction involves systemic trust in relation to the general properties of a social or political system (one's attitude to democracy could be an example) (Sztompka, 2007, pp. 103-109). There need to be considered possible relations occurring between different types of trust, described, e.g., by the institutional theory of generalised trust proposed by Rothstein and Stolle (2003, pp. 191$209 ; 2002$, p. 27). From their reflections emerges the conclusion that the measure of institutional trust conditions the citizens' sense of security, influences their perception of the behaviour of others members of society and through these channels it can affect the level of generalised social trust.

The components of social capital change at a different pace and are characterised by varying levels of sensitivity to the action of external stimuli, including those generated by the real sphere of economy. By default, it could be assumed that the behavioural dimension is more sensitive to changing macroeconomic environment, whereas the cognitive dimension is relatively stable (changing in a generational perspective). Also, the respective types of trust may react differently to changes in the macro-environment. This pertains especially to institutional trust, and in certain cases also to systemic trust. This topic is subjected to in-depth analysis in subsequent sections of the study.

\section{Mechanism of the creation and erosion of social capital in economic crisis condition - literature review}

Ultimately, social capital arises from interpersonal relations. The present condition of social capital is a remnant of previous collective actions. Whereas actions taken today determine the emergence of new forms of social capital. Therefore, social capital determinants are the circumstances accompanying the formation of social bonds. In the most general approach, these conditions can be divided into two groups (Parts, 2013, p. 5):

- of a microeconomic character - psychological and socio-economic characteristics of an individual, such as personal income, education level, family and social status, personal values and experiences which determine the opportunities and motivations of individuals to 'invest' in social capital (to participating in social relations);

- of a macroeconomic character - contextual or systemic factors, such as the general level of socio-economic development, quality and reliability of formal institutions, the level of economic and social inequalities, 
and also preceding inherited patterns of cooperation and trust (so-called 'path dependance').

The variables mentioned run in a peculiar manner under economic crisis conditions. To be precise, economic crisis denotes in the present study a downward phase of an economic cycle (recession) characterised by a slowdown or decrease of the production rate. This is usually accompanied by reduced aggregated demand, decreased employment and increased unemployment, characterised by varying levels of intensity in different economies (Milewski, 2002, pp. 513-514). In the context of the effect of such changes on social capital it can be noticed that a crisis imposes macroeconomic limitations on behaviours of entities participating in the economy - under the crisis condition the society experience more economic risk.

The basic channels of the interaction between an economy and social capital - during a crisis - are the changes of the level of income (an absolute and relative change of the income position (Fischer \& Torgler, 2006)), resulting from the processes occurring on the labour market (the reduction of employment, the increase of unemployment and the rise of frustrating income inequalities), on the capital market (e.g. the fall of the prices of assets, the erosion of credibility of the market's participants (Tonkiss, 2009)) as well as in the institutional field (the direction of the anti-cyclical economic policy).

A review of the results of (sparse) empirical studies conducted so far leads to the conclusion that the individual types of social bonds and social capital dimensions behave differently under economic crisis conditions. S. Wong (2013, pp. 107-119) points out that under such circumstances in developing economies bonding relations are strengthened bridging bonds can both develop or erode. This is because in financial trouble households more often resort to help of family and friends. There also arises the hypothesis that under conditions of economic uncertainty social capital is of more importance to the most poverty-stricken for them it is the sole resource they can rely on ${ }^{1}$. Although, the singular effect of reinforcing family bonds is of a short-, or medium-term at most, since the financial capabilities of friends and family are limited (Moser, 1996).

The deterioration of one's income situation in recession conditions may motivate to taking social initiatives strengthening bridging capital, but it can also be a stimulus to withdrawing from social activity (erosion of this capital), as such initiatives often require the possession of certain resources (time, money) (Wong, 2013, pp. 111-122). For example, in Indonesia during the so-called Asian crisis, between 1997 and 1998 the percentage of people participating in voluntary service decreased by $22 \%$, in community assemblies by $20 \%$, in activities for local communities by $13 \%$ (Frankenberg et al., 1999, p. 39). The observed reduced feeling of community bond in Indonesia was accompanied by a rise in individual initiatives, which according to the authors should impact the bridging social capital of this society in the future.

1 Wong uses the example of Asian countries and their reaction to the crisis at the end of the 1990s. 
Whereas observations of social capital in Iceland before and after the economic crisis struck in 2008 indicate that not only family bonds were strengthened, but also those outside of the family, civic, social and political activity of Icelanders was intensified, yet this was accompanied by an increase of the group of those discontented with the functioning of democracy. However, the authors point out that not all of the changes described were caused by the economic crisis. In particular, the observed strengthening of family bonds occurred not only as a result of the crisis, but it was a continuation of long-term trends of social capital growth. While the economic crisis affected for the most part an increase of political and social involvement of Icelanders and a lowering of the scale of social and institutional trust (Growiec et al., 2012, pp. 8-14, 16).

A review of the literature yields ambiguous conclusions as to the directions and generalised trust in a time of economic crisis. On the one hand, there are indicated slow (generational) changes of this social capital dimension. On the other hand, there appear suggestions that escalating violence and crime (in conditions of a deteriorated economic situation) may lower the level of generalised trust and intensify attitudes of distrust towards strangers (Fiszbel et al., 2003).

Whereas, there are rather clear-cut results of research on the shortness of the period in which the trust measure changes in regard to people's attitude to various public institutions in a deteriorated economic situation. This was also demonstrated by the economic crisis, initiated in the financial sector in 2007 in USA (which revealed weaknesses of the real sector for example in the Mediterranean countries and of institutional sphere in euro area). Disturbances on the financial market in the first place impaired the credibility of the market's participants and information provided by them. As a result of the erosion of trust, a great number of transactions on the financial market were veritably paralysed, and the level of participation in the market was also lowered (Tonkiss, 2009, p. 197). Next, it translated into reduced trust in financial and governmental institutions, obligated to regulating the financial sector. This is shown explicitly by data gathered as part of a cyclical opinion poll conducted among EU residents, commissioned by The European Parliament (Eurobarometer) (chartl). This mechanism is explained in part by relative deprivation theory, in the light of which general level of trust, as well as trust in state institutions depends on the level of absolute and relative income. The decline of one's absolute and relative income position, is followed by reduction of trust in the parliament and other state institutions (which are the legal and systemic framework for social and economic activity), held responsible for deteriorating income situation (Fischer \& Torgler, 2006, pp. 21-22).

The experiences of Asian and European countries described above indicate that economic crisis can variously affect the formation of the individual social capital dimensions - such effects can be of a positive as well as negative character, and the result of these forces is difficult to estimate. Moreover, social capital variations in economic crisis conditions in specific communities follow different scenarios. Important variables differentiating the course of these processes can 
be the socio-economic development of a country, the social capital condition, the scale of crisis occurrences and the institutional response.

On the basis of the review of literature conducted there can also be formulated a few other observations. There are grounds to suppose that under economic crisis conditions, especially in economies with a modest social capital condition, there can occur temporary drops in the willingness to join new networks of cooperation and taking joint, collective initiatives. On the basis of this observation there can be formulated the assumption that lowered investment activity in the period of deteriorated economic condition may result not only from more uncertainty or worse financial situation, but also in part it could be a result of the action of stimuli activated by the social capital channel. It would also be interesting to investigate the significance of social capital activity for the willingness to generate innovation under such circumstances (seeing as innovative measures develop on the basis of social contacts networks).

Reflecting on reciprocal relations, one could also ask a question: to what extent could the condition of social capital determine the depth and durability of crisis occurrences, and how can the resources of this capital be used effectively, in order to respond to threats brought by economic crisis? Is economic capital able to assist in mitigation of loss resulting from the short-sightedness of politicians or financial speculators? There are put forward arguments (what the example of Iceland would suggest) that non-financial, qualitative resources (like social capital) are not only more flexible in relation to economic environment change, but also it could be assumed that their role is increased in the formulation and implementation of 'anti-crisis' strategies (Growiec et al., 2012, p. $3)$.

\section{Social capital in South European countries before and after 2007}

In order to explain the full context of the social capital changes in South European countries, there are presented mean characteristics of basic macroeconomic variables in the years 2008-2013, describing the course of the economic crisis (own calculations based on Eurostat):

- annual average rate of real GDP change: Greece -4.9\%, Spain -1.1\%, Portugal $-1.4 \%$ (euro area $-0.25 \%$ );

- decrease in the level of employment: Greece 17.8\%, Spain 16.4\%, Portugal $12.7 \%$ (euro area $-2.9 \%$ );

- average unemployment rate: Greece 16.7\%, Spain 20.2\%, Portugal 12.8\% (euro area 9.9\%).

The Mediterranean countries have suffered from the effects of the crisis more severely than other countries of the euro zone. It has been a result of structural underdevelopment of their economies (their lower competitiveness). However, some differences need to be stressed. The difficult situation of Spain and Portugal has deteriorated due to the fact that interest rates, which had been in effect 
in the euro area, have been too low which, consequently, has caused credit boom and the excessive growth of domestic demand. On the other hand, Greece has been prioritizing an expansive budget policy which is focused on increasing expenses (of faulty design). Furthermore, the declarations concerning restructuring programmes, which the Greek government had been making before 2007, have not been consistently implemented. Moreover, there have been attempts to hide this incompetence by distorting statistical data.

Comparing the indices diagnosing the level of political activity and citizens' involvement, before and after the outbreak of the last economic crisis (after 2007), it can be concluded that 'crisis' conditions were reflected to varying extent in the changes of the behavioural component of social capital in South European countries (table 2). First of all, after 2007 Spain saw activation of civil society (this is illustrated by higher indices both of political activity as well as citizens' involvement). Such processes did not happen in Portugal or Greece in those countries participation in political life was systematically reduced. In those countries the period of crisis did not provide stimuli to a manifest increase of civil activity.

The data collected (table 3 ) does not prove the thesis resulting from the observations of social capital changes in developing countries, about the strengthening of bonds between family members and friends during economic crisis. Among the analysed countries, only in Greece (as compared to 1999) the significance attributed to family ties increased (according to an ANOVA non-parametric variance analysis, the changes were statistically significant $p=0.0063)^{2}$.

After 2007, in all of the analysed South European countries, the importance attached to bonds between friends increased ${ }^{3}$. Beside Portugal $(p=0.29)$, the changes can be considered statistically significant (Spain $p=0.003$, Greece $p=0.0036$ ). There cannot be, however, formulated a conclusion that it was only the deteriorated economic situation that underlay the processes observed. In Portugal, they can be the continuation of a long-term trend observed since 1990, whereas for Greece there is too little data to formulate conclusions. Only with regard to Spain there can be ventured an observation that the economic crisis conditions redounded to increasing the significance attributed to bonds with friends. At the same time, in Spain there were also strengthened bridging relations, which was by a higher percentage of respondents undertaking activity in an organisation or association (other than a political one) - table 2. Such activation did not take place neither in Portugal nor Greece.

According to theoretical premises, the worsening of the economic situation after 2007 did not have a significant impact on the cognitive dimension of social capital, as regards standards of reciprocity or the generalised level of social trust (table 4). Although after 2008 there can be noticed an improvement of these

${ }^{2}$ In Spain and Portugal the significance attached to family bonds dropped (for Spain $p=0.1954$ - a statistically insignificant change, for Portugal $p=0.00)$.

3 These are bonds which, according to theory are characterised by lower functionality, as regards the provision of long-term grounds for development than bridging. 
fragmentary social capital indices in Spain and opposite changes in Portugal (in Greece the indices remained at a level similar to the pre-crisis period).

In all of the analysed countries, there occurred, however, a marked decrease of institutional and systemic trust (table 4). In response to the negative demand shock (which triggered the increase of unemployment) occurred - in the first period (2008-2009) in Spain, Portugal and Greece — large fiscal stimuli. However, since 2010 the public spending have been reduced due to the high government debt. The contractionary fiscal policy had the negative impact on growth in the short term. The decline of one's absolute and relative income position, was followed by reduction of trust in the parliament and other state institutions, held responsible for deteriorating income situation. Among the analysed countries the scale of reduction of trust in parliament and the legal system was the highest in Greece (from 24\% in 2004 to 5\% in 2010). In Spain the initial level of institutional trust was similar to Greece, but the scale of its reduction was lower (from $25 \%$ in 2004 to $12 \%$ in 2010). In Portugal - before 2007 - the level of institutional trust was the lowest among the analysed countries, and after the crisis it dropped to the level observed in Greece. As a result, in 2012, Spain has been characterized by a higher level of trust in in country's parliament than Portugal (which can be attributed to a high level of institutional trust in Spain before 2006) and Greece (in Greece a great decline of trust in parliament and legal system can be related to significant errors of fiscal policy which Greek government has been trying to hide for years, altering data connected with public finances). In result, in Spain a greater percentage of citizens who 'trust' state institutions translates into 'more comfort' of those in government in implementing anti-crisis strategies.

\section{Conclusion}

The deliberations in the paper are concentrated around the directions of social capital change in economic crisis conditions. Studies of the literature and empirical analyses furnish evidence both of the strengthening as well as erosion of this capital in its respective dimensions during economic crisis.

The example of South European countries shows that there cannot be considered a universal pattern of reaction of economic capital to crisis events. The common characteristic of the analysed countries is reduced institutional and systemic trust (linking social capital) and the reinforcement of relations between friends after 2007 (though only in the case of Spain it can be associated with the economic crisis). Whereas the behavioural dimension was characterised by greater variety of social capital changes. The economic crisis triggered increased activation of society in Spain; such changes did not occur in Portugal or Greece. In response to recession, the Spanish society was more eager to reach for social resources than the Greeks or the Portuguese. In comparison to these two countries, Spain, before the crisis outbreak, was characterised by a higher generalised trust index (in 2006 Spain about 25\%; Greece - 17\%, Portugal - 13\%). 
It can therefore be assumed that directions of changes in behavioural dimension of social capital under economic crisis conditions depend on the condition of the cognitive sphere of social capital as well.

The ambiguous effect of a deteriorating economic situation on social capital changes results, firstly, from the nature of this capital - not observable directly, difficult to measure, and secondly — from dynamic and unpredictable reactions of business entities to economic threats, and thirdly — from the contextuality of these processes. As a consequence, it is difficult to determine and predict how short-term reactions will translate into long-term abilities to build social capital. However, it can be remarked that societies with a relatively good condition of this capital (such as Spain) are more inclined to reach for this resource in order to respond to threats brought by economic crisis (this is illustrated by higher indices of civil and political activity). Social capital can therefore be regarded as a significant factor which may facilitate the implementation of 'anti-crisis' strategies.

\section{References}

Coleman, J.S. (1990). Foundations of Social Theory, Cambridge: Harvard University Press.

European Commission. (2014). Public Opinion in the European Union. First results, doi:10.2775/68303.

European Social Studies Data. (2016). Retrieved 30.12.2016 from http:// nesstar.ess.nsd.uib.no.

European Values Study. (2016). Retrieved 30.12.2016 from http://www.europeanvaluesstudy.eu.

Fischer, J.A.V., \& Torgler, B. (2006). The Effect of Relative Income Position on Social Capital. Economics Bulletin, 26(4).

Fiszbel, A., Giovagnoli, P., \& Aduriz, I. (2003). The Argentine crisis and its impact on household welfare, CEPAL Review, 79.

Frankenberg, E., Duncan, T., \& Beegle, K. (1999). The real costs of Indonesian's economic crisis: preliminary findings from the Indonesian family life surveys. Labour an Population Program Working Paper Series, 99-04.

Fukuyama, F. (2000). Wielki wstrząs. Natura ludzka a odbudowa porządku spotecznego. Warszawa: Politeja.

Grootaert, C., \& van Bastelaer, T. (Ed.). (2002). Understanding and Measuring of Social Capital. A Multidisciplinary Tool for Practitioners. doi:10.1596/0-8213-5068-4.

Growiec, K., Vilhelmsdóttir, S., \& Cairns, D. (2012). Social Capital and Financial Crisis: The Case of Iceland. CISE e-Working Papers, 138.

Kostro, K. (2005). Kapitał społeczny w teorii ekonomicznej. Gospodarka Narodowa, 7-8.

Matysiak, A. (2005). Reprodukcja kapitału społecznego w gospodarce. Zeszyty Naukowe Akademii Ekonomicznej w Poznaniu, 58. 
Milewski, R. (Ed.). (2002). Podstawy ekonomii. Warszawa: PWN.

Moser, C. (1996). Confronting crisis: a comparative study of household responses to poverty and vulnerability in four poor urban communities. Environmentally sustainable development studies and monographs series, No 8, Washington: World Bank.

Parts, E. (2013). The dynamics and determinants of social capital in the European Union and Neighbouring Countries. Discussions on Estonian economic policy: Theory and practice of economic policy in the European Union, 1. doi:10.2139/ ssrn.2336016.

Putnam, R.D. (1995a), Turning in, turning out: the strange disappearance of social capital in America. Political Science and Politics, 28(04). doi:10.1017/ s1049096500058856.

Putnam, R.D. (1995b). Demokracja w dziataniu społecznym. Kraków: Znak.

Rothstein, B., \& Stolle D. (2002). How Political Institutions Create and Destroy Social Capital: an Institutional Theory of Generalized Trust. Paper presented at the annual meeting of the American Political Science Association, Boston, Massachusetts, August 28, 2002.

Rothstein, B., \& Stolle, D. (2003). Social Capital, Impartiality, and the Welfare State: An Institutional Approach. In M. Hooghe, \& D. Stolle (Eds.), Generating Social Capital. Civil Society and Institutions in Comparative Perspective. New York and Houndmills, Basingstoke: Palgrave Macmillan.

Sztompka, P. (2007). Zaufanie. Fundament społeczeństwa. Kraków: Znak.

Tonkiss, F. (2009). Trust, Confidence and Economic Crisis. Intereconomics, 44(4). doi:10.1007/s10272-009-0295-x.

Wong, S. (2013). From economic meltdown to social crunch: Lesson about social capital and economic crises. Procedia - Social and Behavioral Sciences, 72. doi:10.1016/j.sbspro.2013.02.009.

\section{Acknowledgements}

Author contributions: author have given approval to the final version of the article.

Funding: this research was fully funded by the statutory sources. 


\section{Appendix}

Table 1.

Selected indices diagnosing social capital

\begin{tabular}{|c|c|}
\hline Social capital dimensions & Sample opinion poll questions \\
\hline \multicolumn{2}{|c|}{ Cognitive dimension } \\
\hline \multirow{3}{*}{$\begin{array}{l}\text { Generalised social trust } \\
\text { Standards of reciprocity } \\
\text { in relation to public institutions }\end{array}$} & $\begin{array}{l}\text { In general, do you think that most people can be trust- } \\
\text { ed, or you can't be too careful?; }\end{array}$ \\
\hline & $\begin{array}{l}\text { Degree of accepting the view: Most of the time people } \\
\text { try to be helpful or mostly looking out for themselves }\end{array}$ \\
\hline & $\begin{array}{l}\text { Level of trust (e.g., on a scale 1-9) to: state parliament, } \\
\text { European Parliament, legal system, government, etc. }\end{array}$ \\
\hline \multicolumn{2}{|c|}{ Structural dimension - cooperation networks } \\
\hline \multirow{3}{*}{$\begin{array}{l}\text { Association activity (bridging social capital) } \\
\text { Bonds between family members, friends, neighbours } \\
\text { (bonding social capital) }\end{array}$} & $\begin{array}{l}\text { Activity in another organisation or association (others } \\
\text { than a political party) in the last } 12 \text { months; }\end{array}$ \\
\hline & How important is family in your life? (on a scale $1-4$ ); \\
\hline & $\begin{array}{l}\text { How important are friends and acquaintances in your } \\
\text { life? (on a scale 1-4). }\end{array}$ \\
\hline \multicolumn{2}{|c|}{ Behavioural dimension } \\
\hline \multirow{4}{*}{ Civil society indices, manifestations of joint action } & $\begin{array}{l}\text { Percentage of respondents who contacted politicians } \\
\text { in the last } 12 \text { months; }\end{array}$ \\
\hline & $\begin{array}{c}\text { Activity in a party/political organisation in the last } 12 \\
\text { months, }\end{array}$ \\
\hline & $\begin{array}{c}\text { Participation in a legal demonstration in the last } 12 \\
\text { months, }\end{array}$ \\
\hline & Signing a petition in the last 12 months. \\
\hline
\end{tabular}

Source: own preparation based on European Values Study (2016). 
Table 2.

Politics and civic engagement in South European countries (\% of answers)

\begin{tabular}{|c|c|c|c|c|c|c|}
\hline Year/Country & 2002 & 2004 & 2006 & 2008 & 2010 & 2012 \\
\hline \multicolumn{7}{|c|}{ Contacted politician or government official — last 12 months } \\
\hline Greece & 14.5 & 13.5 & - & 10.0 & 8.6 & - \\
\hline Spain & 11.7 & 12.6 & 12.0 & 10.1 & 13.5 & 13.2 \\
\hline Portugal & 11.2 & 5.4 & 8.2 & 6.4 & 5.0 & 5.6 \\
\hline \multicolumn{7}{|c|}{ Worked in political party or action group — last 12 months } \\
\hline Greece & 5.0 & 5.8 & - & 3.9 & 2.9 & - \\
\hline Spain & 5.8 & 7.4 & 5.1 & 3.1 & 7.0 & 7.7 \\
\hline Portugal & 3.9 & 1.7 & 1.8 & 1.4 & 1.8 & 1.4 \\
\hline \multicolumn{7}{|c|}{ Worked in another organisation or association — last 12 months } \\
\hline Greece & 5.7 & 5.1 & - & 3.9 & 4.7 & - \\
\hline Spain & 14.6 & 17.8 & 14.3 & 10.2 & 17.6 & 22.0 \\
\hline Portugal & 5.3 & 2.6 & 3.7 & 3.0 & 4.0 & 4.0 \\
\hline \multicolumn{7}{|c|}{ Signed petition last 12 months } \\
\hline Greece & 4.6 & 3.1 & - & 4.8 & 5.1 & - \\
\hline Spain & 24.0 & 24.6 & 22.8 & 17.6 & 26.2 & 33.2 \\
\hline Portugal & 6.8 & 4.4 & 4.8 & 5.0 & 5.8 & 7.3 \\
\hline \multicolumn{7}{|c|}{ Taken part in lawful public demonstration last 12 months } \\
\hline Greece & 4.3 & 4.8 & - & 5.9 & 10.3 & - \\
\hline Spain & 16.1 & 33.6 & 18.2 & 15.9 & 18.2 & 25.9 \\
\hline Portugal & 4.2 & 3.5 & 3.5 & 3.7 & 3.0 & 7.4 \\
\hline
\end{tabular}

Source: own preparation based on European Social Studies Data (2016).

Table 3.

Selected indicators of bridging social capital

\begin{tabular}{cccc}
\hline Year/Country & Spain & Greece & Portugal \\
\hline & 'How important in your life is family' (mean answers to the question) & 3.59 \\
1990 & 3.81 & - & 3.83 \\
1999 & 3.85 & 3.78 & 3.74 \\
2008 & 3.82 & 3.85 & 3.02 \\
'How important in your life are friends and acquaintances?' (mean answers to the question) \\
1990 & 3.35 & - & 3.21 \\
1999 & 3.25 & 3.30 & 3.25 \\
2008 & 3.33 & 3.40 & \\
\hline
\end{tabular}

Answers: 4 - very important; 3 - quite important; 2 - not all important.; 1 - not at all important. Source: own preparation based on European Values Study (2016). 
Table 4.

General and institutional trust (\% of answers)

\begin{tabular}{|c|c|c|c|c|c|c|}
\hline Country & 2002 & 2004 & 2006 & 2008 & 2010 & 2012 \\
\hline \multicolumn{7}{|c|}{ General (social) trust — 'most people can be trusted' } \\
\hline Greece & 15.0 & 17.0 & - & 15.9 & 16.5 & - \\
\hline Spain & 27.4 & 25.1 & 26.1 & 24.2 & 25.1 & 27.6 \\
\hline Portugal & 14.4 & 13 & 17.8 & 12.6 & 12.3 & 12.6 \\
\hline \multicolumn{7}{|c|}{ 'Most of the time people are helpful' } \\
\hline Greece & 8.7 & 9.1 & - & 9.8 & 8.4 & - \\
\hline Spain & 19.1 & 17.1 & 16.9 & 19.6 & 21.3 & 21.9 \\
\hline Portugal & 11.0 & 11.5 & 15.3 & 11.0 & 13.7 & 10.5 \\
\hline \multicolumn{7}{|c|}{ Trust in the legal system } \\
\hline Greece & 54.0 & 39.3 & - & 30.4 & 20.3 & - \\
\hline Spain & 18.5 & 24.2 & 29.2 & 19.5 & 20.3 & 15.6 \\
\hline Portugal & 16.3 & 14.5 & 14.9 & 14.7 & 9.1 & 10.2 \\
\hline \multicolumn{7}{|c|}{ Trust in country’s parliament } \\
\hline Greece & 28.6 & 24.1 & - & 14.0 & 5.0 & - \\
\hline Spain & 24.4 & 25.4 & 27.5 & 25.2 & 16.0 & 11.8 \\
\hline Portugal & 17.4 & 9.6 & 12.0 & 11.3 & 6.1 & 4.4 \\
\hline \multicolumn{7}{|c|}{ Trust in the European Parliament } \\
\hline Greece & 41.4 & 36.1 & - & 21.6 & 7.8 & - \\
\hline Spain & 21.6 & 26.6 & 25.4 & 23.2 & 18.3 & 14.6 \\
\hline Portugal & 20.5 & 13.8 & 20.1 & 18.0 & 10.1 & 6.9 \\
\hline
\end{tabular}

Source: own preparation based on European Social Studies Data (2016).

Chart 1.

Institutional trust in EU countries in the years 2004-2014 (in \%EU)

45

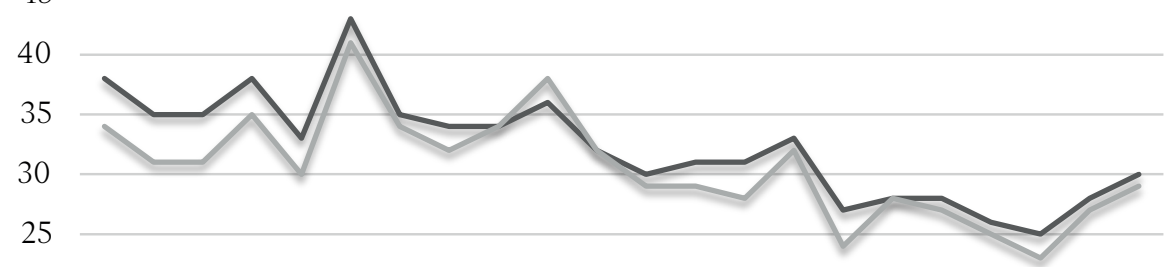

20

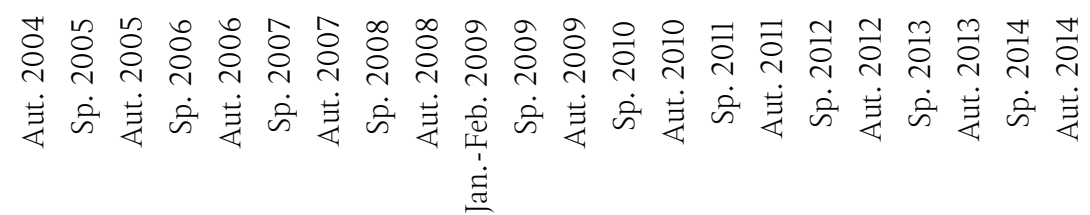

—The National Parliament

'For each of the following media and institutions, please tell me if you tend to trust it or tend not to trust it'.

Source: European Commission (2014, p. 8). 